\title{
Effects of Varying Doses of Nitrogen and Phosphorus on Vegetative Growth, Flowering and Fruit Quality of Cape Gooseberry (Physalis peruviana Linn)
}

\author{
Sunna Deepti*, A.K. Singh and Kunwar Avinash Pratap Singh \\ Department of Horticulture, College of Horticulture and Forestry, \\ Narendra Deva University of Agriculture and Technology, \\ Narendra Nagar (Kumarganj), Faizabad 224229 (U.P.), India
}

*Corresponding author

\begin{tabular}{l} 
K e y w o r d s \\
Cape gooseberry, \\
$\begin{array}{l}\text { Physalis peruviana, } \\
\text { Nitrogen, Phosphorus, } \\
\text { Vegetatitive growth, } \\
\text { Quality attributes }\end{array}$ \\
\hline Article Info \\
\hline $\begin{array}{l}\text { Accepted: } \\
\text { 04 January } 2018 \\
\text { Available Online: } \\
\text { 10 February } 2018\end{array}$ \\
\hline
\end{tabular}

A B S T R A C T

The experiment was carried out at Main Experiment Station of Horticulture department, Narendra Deva University of Agriculture and Technology, Faizabad (U.P.) during the year 2015-16 to evaluate the effect of varying doses of nitrogen and phosphorus on vegetative growth, flowering and fruit quality of cape gooseberry. The experiment was conducted in Factorial Randomized Block Design with twelve treatments comprising of 4 levels of Nitrogen, i.e., $(75,100$, $125,150 \mathrm{~kg} / \mathrm{ha}$ ), and 3 levels of Phosphorus $(60,80,100 \mathrm{~kg} / \mathrm{ha})$ the doses of Nitrogen and Phosphorus were applied in two splits. The results were recorded on the characters viz., plant height $(\mathrm{cm})$, number of primary and secondary branches / plant, days taken to first flowering, days taken to $50 \%$ flowering and quality attributes viz. TSS, Ascorbic acid and acidity. On the basis of experimental finding it is concluded that the application of (N150:P100) $\mathrm{kg} / \mathrm{ha}$ was suitable doses for better plant vegetative growth and fruit quality of Cape gooseberry.

\section{Introduction}

The cape gooseberry (Physalis peruviana Linn) is annual minor fruit crop belongs to family Solanaceae. Plant is annual and perennial herb bearing globular fruit, each include in inflated calyx, which become papery on maturity and look like Chinese lantern. It is also commonly called as poha berry in Hawaii, Golden berry in South Africa and Rashbhari, Makoi or Tepari in India (Gupta and Roy, 1980). The name of cape gooseberry is most probably derived from the name of "Cape of Good Hope" of South Africa, where it was commercially grown (Chattopadhyay, 1996).

The fruit is a smooth berry, resembling a miniature, spherical, looks like yellow tomato. Removed from its bladder like calyx, it is about the size of a marble, about $1-2 \mathrm{~cm}$ in diameter in size. Like a tomato it contains numerous seeds. It is bright yellow to orange in colour, and it is sweet when ripe, with a 
characteristic mildly tart flavour, making it ideal for snacks, pies or jams.

The fruits of the plant that is commercialized are characterized for their nutritional value. They are an excellent source of vitamin A, vitamin $\mathrm{C}$, iron, and some of the vitamin $\mathrm{B}$ complex. The protein and phosphorus levels in the fruits are exceptional high as well as pectin that used in jam production (Fischer, 1995). The name of cape gooseberry in most view, its importance is not less than any other fruit crops.

The edible portion of berry contains $11.5 \%$ carbohydrates, $1.8 \%$ protein, $0.2 \%$ fat, $3.2 \%$ fibre, $0.6 \%$ mineral matter and $43-49 \mathrm{mg}$ ascorbic acid per $100 \mathrm{~g}$ edible portion of fruit (Khan and Gowder, 1955) The fruit also contains carotene as vitamin A 2380 IU (Anonymous, 1969), pectin 0.9\% (Majumder and Bose, 1979) and bioflavonoides (Hayes, 1966). The ripe fruit are eaten as such and use in making excellent quality of jelly, sauces and particularly jam for which it is called as the "Jam fruit of India" (Majumder, 1979). The fruits are also attractive sweet when dipped in chocolate or other glazes or pricked and rolled in sugar.

Based on the available literature, it is evident that very little research work has been carried out so far on the vegetative and floral responses, quality attributes of Cape gooseberry to nitrogen, phosphorus application in many parts of the country especially in the northern regions.

Keeping all these things in view, the present investigation was planned to study the influence of graded levels of Nitrogen and Phosphorus combinations on the vegitative growth and fruit yield of Cape gooseberry and elucidation of partitioning of these nutrients to different parts of the plant in enhancing the fruit quality.

\section{Materials and Methods}

The experiment was conducted at Main Experiment Station, Department of Horticulture, Narendra Deva University of Agriculture and Technology, Narendra Nagar (Kumarganj). Faizabad (U.P) during the period of 2015-2016. The experimental site falls under sub-tropical climatic zone of eastern parts of India, which is situated under Indo-gangetic plains. Faizabaad district comes under eastern region of Uttar Pradesh, The experimental area had a soil sandy loam in texture with good fertility. The experimental was laid out in a factorial randomized lock design with three replications. The plot size was $3.6 \mathrm{~m} \times 3.0 \mathrm{~m}$ and Spacing $60 \mathrm{~cm} \times 60 \mathrm{~cm}$. and total number of treatment combination are 12 consisting of 4 levels of nitrogen viz., $\mathrm{N}_{1}$ (75 kg N/ha), $\mathrm{N}_{2}(100 \mathrm{~kg} \mathrm{~N} / \mathrm{ha}) \mathrm{N}_{3}(125 \mathrm{~kg}$ $\mathrm{N} / \mathrm{ha}), \mathrm{N}_{4}(150 \mathrm{~kg} \mathrm{~N} / \mathrm{ha})$ and 3 levels of phosphorus $\mathrm{P}_{1}(60 \mathrm{~kg} / \mathrm{ha}), \mathrm{P}_{2}(80 \mathrm{~kg} / \mathrm{ha}), \mathrm{P}_{3}$ $(100 \mathrm{~kg} / \mathrm{ha})$ with a recomended uniform dose of potassium $(60 \mathrm{~kg} / \mathrm{ha})$ application to all treatments. A recommended doses of FYM was also applied to all treatments uniformly. The straight fertilizer viz., Urea, Single Super Phosphate and Murate of Potash were used as the source of $\mathrm{N}, \mathrm{P}_{2} \mathrm{O}_{5}$ and $\mathrm{K}_{2} \mathrm{O}$ respectively. Half dose of nitrogen and full dose of phosphorous and constant dose of potassium as per requirement of respective treatments were applied before transplanting as basal application while, remaining half doses of nitrogen was top dressed after 30 days of transplanting of the seedlings. Estimation of nutrient status in the soil and plant samples was done in the laboratory by adopting the standard procedures established by several research workers. Available organic carbon in the soil (Walkley and Black, 1947), nitrogen content in the soil and plant samples was estimated by Microkjeldahl's method described by Tandon (1993), phosphorous content in the soil and plant samples was estimated by vando molbdo phosphoric acid 
yellow colour method described by Tandon (1993), potassium content in the soil and plant samples was estimated by flame photometric method described by Jackson (1973). The data collected on each character was subjected to statistical analysis by ANOVA technique as described by Panse and Sukhatme (1967). The treatment means were compared by using the least significant difference values calculated at $5 \%$ level of significance.

\section{Results and Discussion}

Among different essential plant nutrients nitrogen and phosphorus are supposed to be more important with respect to vegetative growth and quality of plant, because these nutrients required in larger quantities for growth and fruit development. Nitrogen is an integral constituent of protein, amino acid, chlorophyll, alkaloids and other biochemical compound in plant. Phosphorus is consider essential constituent of nucleic acid, phospholipids, the co-enzyme, NAD and NADP, ATP and other high energy compound it helps in rapid root development, facilitating carbohydrate translocation and metabolic process in plant. The deficiency of nitrogen and phosphorus affect the vegetative growth, flowering and economic yield of the cape gooseberry (Garg and Singh, 1975). Therefore an adequate supply of nitrogen and phosphorus is necessary for higher yield and quality of fruit. During the course of investigation results obtained on various parameters due to Nitrogen and phosphorus application are described here.

\section{Vegetative growth characters}

The height of plant was influence significantly due to application of Nitrogen and phosphorus. The taller plant were observed with application of (N150:P100) $\mathrm{kg} / \mathrm{ha}$ and the shortest plant were measured in (N75:P60) $\mathrm{kg} / \mathrm{ha}$ where less nitrogen and phosphorus fertilizer applied, the probable reason for increased plant height with highest levels of nitrogen and phosphorus application is obvious as more uptake of these nutrient during plant growth and is needed for more protein and protoplasm synthesis for higher rate of meiosis, results in better photosynthesis and plant growth and ultimately increased the plant height. These results are enclosed conformity to the finding of Sharma and Mann (1971) in tomato and Singh et al., (1977) in tomato.

Number of branches per plant was also significantly increased due to nitrogen and phosphorus application. The higher number of branches was recorded with the application of (N150:P100) $\mathrm{kg} / \mathrm{ha}$ followed by (N150:P80) $\mathrm{kg} \mathrm{NPK} / \mathrm{ha}$ and it was minimum in (N75:P60) $\mathrm{kg} / \mathrm{ha}$ increased in number of branches per plant due to application attributed to more availability of applied nutrient specially nitrogen, which tends to vigorous growth of plants remitting profused branching Sharma and Mann (1972) also recorded maximum number of branches with application of $150 \mathrm{~kg}$ nitrogen/ha in tomato.

The data pertaining to Table 1 showed that the plant height was significantly influenced by different levels of nitrogen and phosphorus. The interaction between nitrogen and phosphorus were also found significant. Plant height varies significantly with the increasing level of nitrogen ranges from $77.80 \mathrm{~cm}$ to 110.16. The maximum plant height $110.16 \mathrm{~cm}$ in cape gooseberry was recorded under nitrogen $\mathrm{N}_{4}(150 \mathrm{~kg} / \mathrm{ha})$ which was found significantly superior over rest of the treatments followed by $\mathrm{N}_{3}(125 \mathrm{~kg} / \mathrm{ha})$ with $99.57 \mathrm{~cm}$ height while minimum plant height i.e. $(77.80 \mathrm{~cm})$ was recorded in $\mathrm{N}_{1}$. The plant height was significantly increased with the various dose of phosphorus. The maximum plant height $97.18 \mathrm{~cm}$ in was recorded under $\mathrm{P}_{3}(100 \mathrm{~kg} / \mathrm{ha})$ which was found significantly 
superior over rest of the treatments and followed by $\mathrm{P}_{2}(80 \mathrm{~kg} / \mathrm{ha})$ with $94.98 \mathrm{~cm}$ while minimum plant height i.e. $91.08 \mathrm{~cm}$ was recorded. The interaction between nitrogen and phosphorus treatments for Plant height was also found significant in cape gooseberry. The tallest plant $(112.41 \mathrm{~cm})$ was measured in $\mathrm{N}_{4} \mathrm{P}_{3} \quad$ (N125:P100) which was found significantly at par with $\mathrm{N}_{4} \mathrm{P}_{2}(\mathrm{~N} 150: \mathrm{P} 80)$ and $\mathrm{N}_{4} \mathrm{P}_{1}$ (N150:P60) with $(110.73 \mathrm{~cm})$ and107.73 $\mathrm{cm}$ respectively. The minimum height 74.05 $\mathrm{cm}$ was measured in $\mathrm{N}_{1} \mathrm{P}_{1}(\mathrm{~N} 75: \mathrm{P} 60)$

The data pertaining to Table 2 indicated that the number of primary branches per plant was significantly influenced by different levels of nitrogen and phosphorus.

In case of nitrogen, the maximum number of primary branches per plant (13.31) was recorded with application of $\mathrm{N}_{4}(150 \mathrm{~kg} / \mathrm{ha})$ followed by $\mathrm{N}_{3} \quad(125 \mathrm{~kg} / \mathrm{ha})$ with 9.64 branches. While, the minimum number of branches per plant (4.44) were recorded in $\mathrm{N}_{1}$.

The number of primary branches was significantly increased with the various dose of phosphorus. The maximum number of primary branches (9.51) was recorded under $\mathrm{P}_{3}(100 \mathrm{~kg} / \mathrm{ha})$ which was found significantly at par with $\mathrm{P}_{2}(80 \mathrm{~kg} / \mathrm{ha}) 8.46$ branches while minimum number of primary branches i.e. 7.48 was recorded in $\mathrm{P}_{1}$.

The interaction effect of nitrogen and phosphorus were also found significant. The maximum number of branches was recorded in $\mathrm{N}_{4} \mathrm{P}_{3}$ (N125:P100) (14.27) which was found at par with $\mathrm{N}_{4} \mathrm{P}_{2}(\mathrm{~N} 150: \mathrm{P} 80)$ (13.13) and $\mathrm{N}_{4} \mathrm{P}_{1}$ (N150:P60) (12.54) however minimum number of branches were counted in $\mathrm{N}_{1} \mathrm{P}_{1}$ (N75:P60) treatment (4.27).

The data pertaining to Table 3 clearly showed that the number of secondary branches per plant was significantly affected by different level of nitrogen and phosphorus. In case of nitrogen, the maximum number of secondary branches per plant (12.22) was recorded with application of $\mathrm{N}_{4}(150 \mathrm{~kg} / \mathrm{ha})$ followed by $\mathrm{N}_{3}$ (125 kg/ha) with 9.54 branches While, the minimum number of branches per plant (6.47) were recorded in $\mathrm{N}_{1}$.

The number of secondary branches was significantly increased with the various dose of phosphorus. The maximum number of secondary branches (10.18) was recorded under $\mathrm{P}_{3} \quad(100 \mathrm{~kg} / \mathrm{ha})$ which was found significantly superior over rest of the treatments and followed by $\mathrm{P}_{2}(80 \mathrm{~kg} / \mathrm{ha})$ with 8.83 branches while minimum number of primary branches i.e. 8.35 was recorded in $\mathrm{P}_{1}$.

The interaction effect of nitrogen and phosphorus were also found significant. The maximum number of branches was recorded in $\mathrm{N}_{4} \mathrm{P}_{3}(\mathrm{~N} 125: \mathrm{P} 100)$ with 12.22 branches followed by $\mathrm{N}_{4} \mathrm{P}_{2}$ (N150:P80) with (11.12) branches, however minimum number of branches were counted in $\mathrm{N}_{1} \mathrm{P}_{1}$ (N75:P60).

\section{Flowering attributes}

The NPK application proved effective to increase number of flowers per plant. Maximum number of flowers per plant was recorded with application of highest dose of (N150:P100) kg/ha followed by (N150:P80) $\mathrm{kg} \mathrm{NPK} /$ ha and it was minimum in (N75:P60) $\mathrm{kg} / \mathrm{ha}$. This might be due to increased photosynthetic efficiency and rate of assimilation due to nitrogen and phosphorus application, which reflects on vigorous growth of plant and ultimately remitting profuse flowering. Prasad et al., (1985) also found similar results in cape gooseberry due to application while phosphorus and potassium non-significant influence. The beneficial effect of phosphorus and fertilizer on flowering in tomato was also reported by Mehla et al., (2000) and Sahoo et al., (2002). 
Observations recorded and days taken to flowering after transplanting shown delayed flowering due to nitrogen and phosphorus fertilizer. The earliest flowering was noticed without nitrogen and phosphorus application and it was gradually delayed with increased the nitrogen and phosphorus levels and observed maximum with (N150:P100) $\mathrm{kg} / \mathrm{ha}$ followed by (N150:P80) $\mathrm{kg}$ NPK/ha and it was minimum in (N75:P60) $\mathrm{kg} / \mathrm{ha}$. The delayed flowering under higher levels of nitrogen and phosphorus fertilizer might be attributed to the pronounced effect of nitrogen, which is more responsible for plant growth by enhancing its vegetative phase. Delayed flowering due to nitrogen application was also reported by Singh and Singh (1992) in tomato.

The data pertaining to Table 4 showed that the days taken to the first flower initiation were significantly influenced by different levels of nitrogen and phosphorus.

The nitrogen treatment significantly influence with the number of days required for opening to first flower in cape goose berry. The minimum 66.62 days were required with $\mathrm{N}_{1}$ for initiation of first flower followed by 71.76 days in $\mathrm{N}_{2}(125 \mathrm{~kg} / \mathrm{ha})$ and $\mathrm{N}_{3}(100 \mathrm{~kg} / \mathrm{ha})$ by 75.09. The maximum number of days required for initiation of first flower (81.06 days) was recorded with $\mathrm{N}_{4}(150 \mathrm{~kg} / \mathrm{ha})$ which was found significantly superior over rest of the treatments. The interaction between nitrogen and phosphorus treatments for plant height was also found significant in cape gooseberry. The minimum days taken to first flower initiation was recorded in $\mathrm{N}_{1} \mathrm{P}_{2}$ (64.87 days) (N75:P80) while maximum days taken to first flower initiation was noted is $\mathrm{N}_{4} \mathrm{P}_{3}(85.07$ days) (N150:P100)

The data pertaining to Table 5 shows that days taken to $50 \%$ flowering was significantly influenced by different levels of nitrogen and phosphorus. The nitrogen treatment significantly influence with the number of days required for $50 \%$ flowering in cape goose berry. The minimum 88.68 days were required with $\mathrm{N}_{1}$ for initiation of $50 \%$ flowering followed by $\mathrm{N}_{2}(125 \mathrm{~kg} / \mathrm{ha})$ with 93.80 days. The maximum number of days required for initiation of 50\% flowering (103.06 days) was recorded with $\mathrm{N}_{4}(150 \mathrm{~kg} / \mathrm{ha})$ which was found significantly superior over rest of the treatments.

The days taken to $50 \%$ flowering was significantly increased with various dose of phosphorus.

The minimum days taken to $50 \%$ flowering 93.98 days was recorded under $\mathrm{P}_{1}(60 \mathrm{Kg} / \mathrm{ha})$ which was found significantly superior over rest of treatments and followed by $\mathrm{P}_{2}(80$ $\mathrm{kg} / \mathrm{ha}$ ) with 95.43 days while maximum days taken to $50 \%$ flowering i.e.93.98 was recorded in $\mathrm{P}_{1}$.

The interaction between nitrogen and phosphorus treatments for plant height was also found significantly in cape gooseberry. The minimum days taken to first flower initiation was recorded in $\mathrm{N}_{1} \mathrm{P}_{1}$ (87.53 days) (N75:P60) followed by $\mathrm{N}_{1} \mathrm{P}_{2}$ (88.40 days) (N75:P80) while maximum days taken to first flower initiation was noted is $\mathrm{N}_{4} \mathrm{P}_{3}$ (105.53 days) (N150:P100).

\section{Quality characters of fruits}

Fruit juice was increased significantly due to nitrogen and phosphorus application and the maximum juice percentage was recorded with application of (N150:P100) $\mathrm{kg} / \mathrm{ha}$ and the lowest were measured in (N75:P60) kg/ ha.

It seems that nitrogen and phosphorus application increased the weight and volume of fruit with more juice percentage. Similar results have also been observed by Prasad et al., (1985) 
Table.1 Effect of varying doses of nitrogen and phosphorus on plant height $(\mathrm{cm})$ in cape gooseberry

\begin{tabular}{|c|c|c|c|c|c|}
\hline phosphorus & \multicolumn{5}{|c|}{ Nitrogen } \\
\hline & $\mathrm{N}_{1}$ & $\mathrm{~N}_{2}$ & $\mathrm{~N}_{3}$ & $\mathrm{~N}_{4}$ & Mean \\
\hline $\mathrm{P}_{1}$ & 74.05 & 85.07 & 97.86 & 107.35 & 91.08 \\
\hline $\mathrm{P}_{2}$ & 78.52 & 91.25 & 99.43 & 110.73 & 94.98 \\
\hline $\mathrm{P}_{3}$ & 80.85 & 94,03 & 101.42 & 112.41 & 97.18 \\
\hline Mean & 77.80 & 90.11 & 99.57 & 110.16 & \\
\hline & $\mathbf{N}$ & $\mathbf{P}$ & & & $\mathbf{N ~ x ~ P}$ \\
\hline SEm \pm & 1.62 & 1.40 & & & 2.80 \\
\hline C.D at 5\% & 4.74 & 4.10 & & & 8.21 \\
\hline
\end{tabular}

Table.2 Effect of varying doses of nitrogen and phosphorus on number of primary branches in cape gooseberry

\begin{tabular}{|c|c|c|c|c|c|}
\hline & \multicolumn{5}{|c|}{ Nitrogen } \\
\hline $\mathbf{P}_{1}$ & $\mathrm{~N}_{1}$ & $\mathrm{~N}_{2}$ & $\mathrm{~N}_{3}$ & $\mathrm{~N}_{4}$ & Mean \\
\hline $\mathbf{P}_{2}$ & 4.27 & 5.53 & 7.60 & 12.54 & 7.48 \\
\hline $\mathbf{P}_{3}$ & 4.27 & 6.87 & 9.60 & 13.13 & 8.46 \\
\hline Mean & 4.80 & 7.27 & 11.73 & 14.27 & 9.51 \\
\hline & 4.44 & 6.55 & 9.64 & 13.31 & \\
\hline SEm & $\mathbf{N}$ & $\mathbf{P}$ & & & $\mathbf{N} \mathbf{x} \mathbf{P}$ \\
\hline C.D at 5\% & 0.48 & 0.41 & & & 0.83 \\
\hline
\end{tabular}

Table.3 Effect of varying doses of nitrogen and phosphorus on number of secondary branches in cape goose berry

\begin{tabular}{|c|c|c|c|c|c|}
\hline phosphorus & \multicolumn{5}{|c|}{ Nitrogen } \\
\hline $\mathbf{P}_{1}$ & $\mathrm{~N}_{1}$ & $\mathrm{~N}_{2}$ & $\mathrm{~N}_{3}$ & $\mathrm{~N}_{4}$ & Mean \\
\hline $\mathbf{P}_{2}$ & 6.00 & 7.47 & 9.00 & 10.93 & 8.35 \\
\hline $\mathbf{P}_{3}$ & 7.33 & 8.60 & 9.20 & 11.20 & 8.83 \\
\hline Mean & 6.47 & 8.67 & 9.54 & 12.12 & 10.18 \\
\hline & $\mathbf{N}$ & $\mathbf{P}$ & 9.54 & 12.22 & \\
\hline SEm \pm & 0.16 & 0.14 & & & $\mathbf{N ~ x ~ P ~}$ \\
\hline C.D at 5\% & 0.48 & 0.41 & & & 0.28 \\
\hline
\end{tabular}


Table.4 Effect of nitrogen and phosphorus on days to first flower initiation in cape gooseberry

\begin{tabular}{|c|c|c|c|c|c|}
\hline \multirow{2}{*}{ phosphorus } & \multicolumn{5}{|c|}{ Nitrogen } \\
\hline $\mathbf{P}_{1}$ & $\mathrm{~N}_{1}$ & $\mathrm{~N}_{2}$ & $\mathrm{~N}_{3}$ & $\mathrm{~N}_{4}$ & Mean \\
\hline $\mathbf{P}_{2}$ & 67.73 & 71.0 & 73.0 & 78.53 & 72.56 \\
\hline $\mathbf{P}_{3}$ & 64.87 & 71.40 & 74.13 & 79.60 & 72.50 \\
\hline Mean & 66.27 & 72.87 & 78.13 & 85.07 & 75.58 \\
\hline & 66.29 & 71.75 & 75.08 & 81.06 & \\
\hline SEm & $\mathbf{N}$ & $\mathbf{P}$ & & & $\mathbf{N} \mathbf{x} \mathbf{P}$ \\
\hline C.D at 5\% & 0.28 & 0.18 & & & 0.36 \\
\hline
\end{tabular}

Table.5 Effect of nitrogen and phosphorus on days taken to $50 \%$ flowering in cape gooseberry

\begin{tabular}{|c|c|c|c|c|c|}
\hline phosphorus & \multicolumn{5}{|c|}{ Nitrogen } \\
\hline & $\mathrm{N}_{1}$ & $\mathrm{~N}_{2}$ & $\mathrm{~N}_{3}$ & $\mathrm{~N}_{4}$ & Mean \\
\hline $\mathbf{P}_{1}$ & 87.53 & 92.80 & 95.27 & 100.33 & 93.98 \\
\hline $\mathbf{P}_{2}$ & 88.40 & 93.93 & 96.07 & 103.33 & 95.43 \\
\hline $\mathbf{P}_{3}$ & 90.13 & 94.67 & 96.87 & 105.53 & 96.80 \\
\hline Mean & 88.68 & 93.80 & 96.07 & 103.06 & \\
\hline & $\mathbf{N}$ & $\mathbf{P}$ & & & $\mathbf{N} \mathbf{x}$ \\
\hline SEm \pm & 0.29 & 0.25 & & & 0.51 \\
\hline C.D at 5\% & 0.87 & 0.76 & & & 1.50 \\
\hline
\end{tabular}

Table.6 Effect of nitrogen and phosphorus on total soluble solids of cape gooseberry

\begin{tabular}{|c|c|c|c|c|c|}
\hline & \multicolumn{5}{|c|}{ Nitrogen } \\
\hline & $\mathrm{N}_{1}$ & $\mathrm{~N}_{2}$ & $\mathrm{~N}_{3}$ & $\mathrm{~N}_{4}$ & Mean \\
\hline $\mathbf{P}_{1}$ & 11.20 & 13.00 & 13.50 & 14.70 & 13,10 \\
\hline $\mathbf{P}_{2}$ & 11.30 & 13.10 & 14.00 & 15.00 & 13.30 \\
\hline $\mathbf{P}_{3}$ & 12.50 & 13.40 & 14.30 & 15.10 & 13.80 \\
\hline Mean & 11.70 & 13.20 & 13.90 & 14.90 & \\
\hline & $\mathbf{N}$ & $\mathbf{P}$ & & & $\mathbf{N} \mathbf{P}$ \\
\hline SEm & 0.58 & 0.50 & & & 1.00 \\
\hline C.D at 5\% & 1.70 & 1.47 & & & 2.94 \\
\hline
\end{tabular}


Table.7 Effect of nitrogen and phosphorus on ascorbic acid ( $\mathrm{mg} / 100 \mathrm{~g}$ juice) in cape gooseberry

\begin{tabular}{|c|c|c|c|c|c|}
\hline \multirow{2}{*}{ Phosphorus } & \multicolumn{5}{|c|}{ Nitrogen } \\
\cline { 2 - 6 } & $\mathrm{N}_{1}$ & $\mathrm{~N}_{2}$ & $\mathrm{~N}_{3}$ & $\mathrm{~N}_{4}$ & Mean \\
\hline $\mathbf{P}_{1}$ & 40.43 & 43.37 & 45.72 & 47.92 & 44.36 \\
\hline $\mathbf{P}_{2}$ & 41.73 & 44.29 & 46.49 & 48.01 & 45.13 \\
\hline $\mathbf{P}_{3}$ & 42.85 & 45.32 & 46.71 & 48.23 & 45.77 \\
\hline Mean & 41.67 & 44.32 & 46.30 & 48.05 & \\
\hline & $\mathbf{N}$ & $\mathbf{P}$ & & & $\mathbf{N ~ x ~ P ~}$ \\
\hline SEm & 1.15 & 0.99 & & & 1.99 \\
\hline C.D at 5\% & 3.38 & 2.92 & & & 5.85 \\
\hline
\end{tabular}

Table.8 Effect of nitrogen and phosphorus on acidity (\%) in cape gooseberry

\begin{tabular}{|c|c|c|c|c|c|}
\hline Phosphorus & \multicolumn{5}{|c|}{ Nitrogen } \\
& $\mathrm{N}_{1}$ & $\mathrm{~N}_{2}$ & $\mathrm{~N}_{3}$ & $\mathrm{~N}_{4}$ & Mean \\
\hline $\mathrm{P}_{1}$ & 1.12 & 1.24 & 1.32 & 1.78 & 1.36 \\
\hline $\mathrm{P}_{2}$ & 1.20 & 1.26 & 1.34 & 1.80 & 1.40 \\
\hline $\mathrm{P}_{3}$ & 1.23 & 1.29 & 1.49 & 1.92 & 1.48 \\
\hline Mean & 1.18 & 1.26 & 1.38 & 1.83 & \\
\hline & $\mathbf{N}$ & $\mathbf{P}$ & & & $\mathbf{N} \mathbf{x}$ \\
\hline SEm & 0.06 & 0.05 & & & 0.11 \\
\hline C.D at 5\% & 0.17 & 0.15 & & & 0.30 \\
\hline
\end{tabular}

Marked influence on quality characters of fruits viz. total soluble solids, acidity, ascorbic acid, and total sugar contents were found due to variation in nitrogen and phosphorus levels. All these quality characters were increased with increasing levels of nitrogen and phosphorus fertilizers and recorded maximum with application of (N150:P100) $\mathrm{kg} / \mathrm{ha}$ and the lowest were measured in (N75:P60) kg/ ha. The increase in total soluble solids and sugars in fruits due to nitrogen and phosphorus application might be due to fact that these nutrients are related to carbohydrate synthesis. When the nutrients supply became insufficient, the limited synthesized carbohydrate synthesis. When the nutrient supply became insufficient, the limited synthesized carbohydrate meets the requirements of only vegetative parts. Contrary to this, when adequate supply of nutrients is available, the synthesized carbohydrate translocate to the fruits, which ultimately increased the total soluble solids and sugars. The plants grown with luxuriant supply nitrogen and phosphorus, prolonged their bio-chemical process and exhibited high acidity and ascorbic acid content in fruit juice. Similar findings have been reported by Singh et al., (1977) and Prasad et al., (1985)

The persual data present in Table 6 revealed that total soluble solids were significantly affected by different levels of nitrogen and phosphorus treatments. The interaction between nitrogen and phosphorus treatment significantly affect the total soluble solids. The total soluble solids were significantly influenced by different levels of nitrogen treatment. The maximum TSS (14.92) were recorded with $\mathrm{N}_{4}(150 \mathrm{~kg} / \mathrm{ha})$, while minimum number of berry per plant 11.69 were recorded with $\mathrm{N}_{1}$. 
The different phosphorus doses do influenced TSS content non-significantly in cape gooseberry. The maximum TSS 13.83 brix in cape gooseberry was recorded under $\mathrm{P}_{3}(100$ $\mathrm{Kg} / \mathrm{ha}$ ) while, minimum TSS i.e. 13.10 brix were recorded in $\mathrm{P}_{1}$.

The interaction between nitrogen and phosphorus treatments for TSS was found significantly in cape gooseberry. The TSS $15.70^{\circ}$ brix was measured in $\mathrm{N}_{4} \mathrm{P}_{3}$ (N150:P100) which was found significantly at par with $15.00^{\circ}$ brix $\mathrm{N}_{4} \mathrm{P}_{2}$ (N150:P80), $14.70^{\circ}$ brix $\mathrm{N}_{4} \mathrm{P}_{1}$ (N150:P60), $13.40{ }^{0}$ brix $\mathrm{N}_{3} \mathrm{P}_{3}$ (N100:P80), $14.00{ }^{0}$ brix $\mathrm{N}_{3} \mathrm{P}_{2}$ (N125:P80), $13.50{ }^{\circ}$ brix $\mathrm{N}_{3} \mathrm{P}_{1}$ (N125:P60), and $13.40^{\circ}$ brix $\mathrm{N}_{2} \mathrm{P}_{3}$ (N125:P80). The minimum TSS $11.20^{\circ}$ brix was measured in $\mathrm{N}_{1} \mathrm{P}_{1}$ (N75:P60).

The data pertaining to Table 7 revealed that different nitrogen levels and phosphorus increased ascorbic acid content significantly.

The ascorbic acid was significantly influenced by different levels of nitrogen treatment. The maximum ascorbic acid content $48.05 \mathrm{mg} / 100$ $\mathrm{g}$ juice was recorded with $\mathrm{N}_{4}(150 \mathrm{~kg}$ $\mathrm{N} / \mathrm{ha}$ ). While, minimum ascorbic acid i.e. $41.67 \mathrm{mg} / 100 \mathrm{~g}$ juice was recorded with $\mathrm{N}_{1}$. The maximum content of vitamin $\mathrm{C} 45.77$ was found in $\mathrm{P}_{3}$ while, minimum ascorbic acid content (44.36 mg/100g juice) was recorded in $\mathrm{P}_{1}$. It was found non-significant.

The interaction between nitrogen and Phosphorus for ascorbic acid content was also found significant. The maximum vitamin $\mathrm{C}$ was recorded in $\mathrm{N}_{4} \mathrm{P}_{3}(48.23 \mathrm{mg})$ which was found significantly at par with $\mathrm{N}_{4} \mathrm{P}_{2}$ (48.01 $\mathrm{mg}$ ), 47.92mg $\mathrm{N}_{4} \mathrm{P}_{1}$ (N150:P60), $46.71 \mathrm{mg}$ $\mathrm{N}_{3} \mathrm{P}_{3}$ (N100:P80), $46.49 \mathrm{mg} \mathrm{N}_{3} \mathrm{P}_{2}$ (N125:P80), $45.72 \mathrm{mg} \mathrm{N} \mathrm{N}_{3} \mathrm{P}_{1}$ (N125:P60), and $45.32 \mathrm{mg}$ $\mathrm{N}_{2} \mathrm{P}_{3}$ (N125:P80), 44.29 mg N $\mathrm{P}_{2}$ (N125:P60), $43.37 \mathrm{mg} \mathrm{N} \mathrm{N}_{2} \mathrm{P}_{1}$ (N125:P60). $\mathrm{N}_{1} \mathrm{P}_{3}$ (N75:P100), Lowest vitamin $\mathrm{C}$ was found in $\mathrm{N}_{1} \mathrm{P}_{1}$ (40.43mg).
The data pertaining to Table 8 shows that different nitrogen levels and phosphorus increased acidity significantly.

The acidity was significantly influenced by different levels of nitrogen treatment. The maximum acidity $1.83 \%$ was recorded with $\mathrm{N}_{4}(150 \mathrm{~kg} \mathrm{~N} / \mathrm{ha})$ followed by $\mathrm{N}_{3}(125 \mathrm{~kg}$ $\mathrm{N} / \mathrm{ha}) 1.38 \%$. While, minimum ascorbic acid i.e. $1.18 \%$ was recorded with $\mathrm{N}_{1}$.

The interaction between nitrogen and Phosphorus for acidity was also found significant. The maximum acidity was recorded in $\mathrm{N}_{4} \mathrm{P}_{3}(1.92 \%)$ which was found significantly at par with $\mathrm{N}_{4} \mathrm{P}_{2}(1.80 \%)$ and $\mathrm{N}_{4} \mathrm{P}_{1}(1.78 \%)$. Lowest acidity was found in $\mathrm{N}_{1} \mathrm{P}_{1}(1.12 \%)$.

\section{References}

Agele, S. O., Adeyemi, I. and Adebayo. 2007. Nitrogen recovery and utilisation efficiencies for biomass and fruit production in pepper (Capsicum annum L.) as affected by fertilizer management strategies/ methods in a humid zone of Nigeria. Agricultural Journal, 2 (1): 112-120.

Anburani, A. and Manivannan, K. 2002. Effect of integrated nutrient management on growth in brinjal (Solanum melongena L.) cv. Annamalai. South Indian Horticulture, 50 (4/6): 377-386.

Chattopadhyay, T.K. 1996. A Text Book of Pomology. Vol. $2^{\text {nd }}$ Kalyani Publishers, New Delhi.

Girapu, R. K. and Kumar, A. Influence of nitrogen and spacing on growth, yield and economics of cape-gooseberry (Physalis peruviana L.) production. Proceedings of the national symposium on production, utilization and export of underutilized fruits with commercial potentialities, Kalyani, Nadia, West 
Bengal, India, 22-24 November, 2006: 145-149, 2006.

Gupta, S.K. and Roy, S.K. 1980. Multipurpose Cape gooseberry. Indian Hort, 24(4): 11.

Khalid, S., Qureshi, K. M., Hafiz, I. A., Khan, K. S., Qureshi, U. S. 2013. Effect of organic amendments on vegetative growth, fruit and yield quality of strawberry. Pakistan Journal of Agricultural Research 26(2): 104-112.

Muniz, J., Kretzschmar, A.A., Rufato, L., Pelizza, T.R., Marchi, T., Duarte, A.E., Lima, A.P.F. and Garanhani, F. 2011. Conduction systems for physalis production in Southern Brazil. Braz. Mag. Fruit Cult, 33(3): 830-838.

Panse, V.G. and Sukhatme, P.V. 1989. Statistical method for agricultural workers, ICAR, New Delhi.

Patil, M. B., Mohammed, R. G. and Ghadge, P. M. 2004. Effect of organic and inorganic fertilizers on growth, yield and quality of tomato. Journal of Maharashtra Agricultural Universities, 29(2): 124-127.

Praseeda, H.S.R. And Sulladmath, U.V. 1979. Effect of nitrogen, phosphorous and potassium on yield and yield components of hybrid tomato Karnataka. Mysore J. Agric. Sci., 13(3): 271-275.

Sahoo, D., Mahapatra, P., Das A.K. and Sahoo, N.R. 2002. Effect of nitrogen and Potassium on growth and yield of tomato (Lycopersicon esculentum) var. Utlal Kumari. Haryana J. Hort. Sci., 31 (3-4): 213-214.

Sandhu, S. and Gill, B. S. 2011. Effect of integrated nutrient management strategies on growth and yield of Capegooseberry (Physalis peruviana L.). Journal of Horticultural Sciences, 6 (1): 29-32.

Sharma C.B. and Mann, H.S. 1977. Effect of phosphorous and nitrogen nutrition and seasonal variation on growth of tomato. Indian J. Hort., 29 (3-4): 322-329.

Yadav, A.L., Kumar, D., Pathak, Sanjay. 2008. Effect of integrated nutrient Management on physic chemical attributes of phalsa (G. Subinaqualis) Plant Archives. 8(1): 461-463.

Yadav, P., Yadav; H.C. and Singh, Y.P., 2011. Effect of integrated nutrient management nourishment of yield attributes and economic of Papaya (Carica papaya L.) cv. Pusa Dwarf. Plant Arch., 11(1): 307-309.

Yeptho, V., Kanaujia, S. P., Singh, V. B. and Sharma, A. 2012. Effect of integrated nutrient management on, growth yield and quality of tomato under poly-house condition. Journal of Soils and Crops, 22(2): 246-252.

\section{How to cite this article:}

Sunna Deepti, A.K. Singh and Kunwar Avinash Pratap Singh. 2018. Effects of Varying Doses of Nitrogen and Phosphorus on Vegetative Growth, Flowering and Fruit Quality of Cape Gooseberry (Physalis peruviana Linn). Int.J.Curr.Microbiol.App.Sci. 7(02): 126-135. doi: https://doi.org/10.20546/ijcmas.2018.702.016 